\title{
RETHINKING A CULTURAL POLICY FOR NATIONAL SECURITY IN NIGERIA
}

\author{
Emmanuel Ayila Agaku, Ph.D \\ Armed Forces Resettlement Centre \\ Oshodi-Lagos \\ emmagaku@gmail.com \\ Martins Moses Agena \\ Department of Cultural and Creative Arts, \\ Federal College of Education, Zaria \\ martinsagena76@gmail.com
}

\begin{abstract}
Nigeria is in pressing need of a cultural policy that could promote cultural values. The challenge of cultural erosion has affected the capacity of the country to ensure the security and welfare of the people for the sustainable development of the country. This article, therefore, examines the cultural dimensions of the country's national security problem. In addition to deploying qualitative research methodology, the researchers adopt a theoretical exploration of secondary sources for the article. The paper x-rays some related literature that unveil many security challenges that have to do with conflicts in the way of life of the people, such as, the Muslim extremists of Marwa, Maitatsine, El-zakzaki and their liberal counterparts in Kano, Maiduguri, Zaria, Gombe, Yola and so on, at various times. Countless instances of ethno-religious conflicts have occurred between Christians and Muslims in Bauchi, Kano, Kafanchan, Zango-Kataf, Kaduna, and Nasarawa among other parts of Nigeria. There have been sectarian conflicts in Nasarawa, Benue, some parts of South-East, South-West and South-South of Nigeria. More recently, there has emerged some difficult insecurity problems characterised by political violence, Boko Haram terrorists, banditry, kidnapping, cattle rustling, Fulani herdsmen attacks, militancy and so on. In addition to the above-mentioned plethora of insecurity, there are on daily occurrence instances of corruption and crimes such as suicide attacks, armed-robbery, oil theft, rape and so on. The article attempted a theoretical matrix of 'culture of security' and 'security of culture'. The paper therefore recommends a cultural policy could promote cultural education, values, sensitivity, and unity, as well as commitment through participatory communication by nationalist individuals and their involvement in the nation-building efforts, necessary to avert imminent crisis in the country.
\end{abstract}

Keywords: Culture, National Security, Culture of Security, \& Security of Culture

\section{INTRODUCTION}

Culture and national security are so intrinsically linked that contemplating national security architecture without comprehensively factoring in culture can be justifiably accepted as the greatest bane of security design. Culture implicates national security because both are engaged in the transformation of human society for its well-being. Cultural policy as a tool of social engineering is very vital for the survival of the nation. National security is, in a critical sense, shaped by culture. A vital clarification of the material, institutional, and philosophical aspects of culture can help provide a more systematic analysis of the dynamic elements of culture(s) vis-à-vis national security (Abah, 2007). This cultural analysis situates the internal and external dimensions to national security. No country can achieve total safety at all times, and coping with perceived threats to national security can be actualized through the adaptation of the elements of culture to ensure survival of the nation (Oladiran \& Adedevoh, 2007, p.1). According to Okwori (2013, p.1), "Culture is necessary in order to give purpose 
and credibility to one's own existence. Rob people of their culture and you rob them of their reason of being".

Virtually every nation designs strategies to ensure its stability. Such approaches are usually enshrined in a National Security programme. Cultural policy as an instrument of social engineering demands a notion of culture as a strategic instrument (Oladiran \& Adedevoh, 2007, p.1). Tukur (1999, p.4) describes this social engineering process as the deliberate political effort to channel behaviour in the direction that will maximise national objectives. The vital linkage between culture and security at any level is better projected by statements related to the nexus between culture and development. According to Okwori $(2013$, p.2), "the real problem of Africa comes from the inability of those in authority to make the right choice and firm commitment to cultural matters because they underestimate the value of culture in development". Extrapolating from the above statement, the capacity of a nation to survive has to do with her cultural values prevailing at any point in time.

One of the fundamental objectives and directive principles which underpin the policy of the Nigerian government towards its people is "security and welfare of the people". It is, therefore, the primary purpose of Government as provided for, in Chapter II of the Constitution of the Federal Republic of Nigeria, 1999. Given the nationwide import of this duty, driving social security initiatives has been one of the constitutional responsibilities of the Federal Government. However, this responsibility suffers minimal attention, as the government of Nigeria sometimes prefers to paint a picture of a global problem rather than doing the needful. One of the significant challenges that have confronted Nigeria since independence is a rising state of insecurity which has, in most cases been attributed to foreign cultures and sources.

Most of the conflicts are ethno-religious. For instance, violent clashes have occurred between Muslim extremists of Marwa, Maitatsine, El-zakzaki and their liberal counterparts in Kano, Maiduguri, Zaria, Gombe, Yola etc. at various times. Numerous instances of ethno-religious conflicts have occurred between Christians and Muslim in Bauchi, Kano, Kafanchan, ZangoKataf, Kaduna, and Nasarawa among other parts of Nigeria (Gyong, 2017, p.1). There have been sectarian conflicts in Nasarawa, Benue, some parts of South-East, South-West and South-South of Nigeria. More recently, there have emerged severe insecurity challenges characterised by political violence, Boko Haram, banditry, kidnapping, cattle rustling, Fulani herdsmen attacks, militancy, communal clashes and so on (Agena, 2018, p.1).

In addition to the above mentioned plethora of insecurity, there are on daily occurrence instances of corruption and crimes such as, suicide attacks, armed-robbery, oil theft, rape and so on. Most of the security challenges have become sophisticated owing to the influence of foreign cultures. These security challenges have had enormous consequences on the developmental needs of Nigeria. These include mainly the loss of countless lives and properties, arrested and retarded development in various facets of the life of the nation. Nigerian government in recent times pointed accusing fingers on foreigners as the brain behind most of the security challenges in Nigeria. It is therefore imperative of the government to rethink its culture and social security arrangements rather than attributing the security challenges to foreigners (Agena, 2018, p.1).

Part of the reasons why culture is crucial to security intervention or any development effort is because the relationship between culture and development is also double-edged invoking complex of senses. 'The complex of senses indicates a complex argument about the relatio 
between general human development and a particular way of life, and between both and the works and practices of art and intelligence. Within this complex argument there are fundamentally opposed as well as effectively overlapping positions; there are also, understandably, many unresolved questions and confused answers' (Idebe, 2018, p.3). The problems of development are attitude and behaviour related. Attitude and behaviour are processes of cultural seasoning. Yet it is through the same culture that active development is enabled. Culture, therefore, is both the problem and solution in development planning and engaging in development requires engagement with both the problem and solution aspects of culture (Okwori, 2013, p.2).

\section{CONCEPTUAL OVERVIEW OF CULTURE AND NATIONAL SECURITY}

To properly situate the direction of this article, it is imperative to explore the critical concept of culture and how it is vital in national security. To understand culture, we need to understand nature, the world as created and given by God, that we have no control of but to exist within, either by manipulation, domestication or recreation. Once we begin to utilize nature, our human response to the way and manner of utilization then means culture (Okwori, 2013). Culture and national security are interrelated. They sometimes display conflicting variations, which may arise from inconsistencies which we notice in our set of beliefs. Sometimes the challenge to our beliefs may come from outside (Oladiran \& Adedavoh, 2007, p. 1).

Studies by Anthropologists and other related disciplines found that culture has an immense impact on human beings in any society because it helps man to adapt to his society and hence to increase the chances of survival. There is an avalanche of definitions of culture as there are diverse cultures across the globe, although these definitions tend to be similar. Castro-Gomez 2002, p.26) holds that 'culture constitutes a sphere of moral, religious, political, philosophical and technological values that permit man to "humanise" himself, i.e. escape the tyranny of the state of nature'. According to Uroh (1996, p.11), it is evident that 'culture is a product of a people's experience. It is the knowledge of doing things which people have acquired in their attempts to solve some socio-historical problems'.

Also, according to Tylor (1996) as cited in Oladiran \& Adedavoh, (2007, p.95), "culture is 'that complex whole which includes knowledge, belief, art, morals, law, custom and any other capabilities and habits acquired by man as a member of society". Other scholars in their attempt at defining culture have reduced culture to mental phenomena, to ideas or the like in the minds of men. Nicolaides (2018) defines culture as a mental map that guides us in our relations with our surroundings and with other people. Hatch sees culture as 'the way of life of a people'. However, having assessed the various definitions offered by scholars on culture, we can say that 'culture is the totality of the way of life evolved of a people in their attempts to meet the challenge of living in their environment, which gives order and meaning to their social, political, economical, aesthetic and religious norms and modes of organisation.

Cardinal in the appraisal of culture is social control, which helps to ensure conformity to societal norms for an ordered society. Mohammed \& Ihidero (2018) posit that virtually every culture embodies three separate but related spheres, namely, universal, alternative and specialties. Uchendu (1988) as cited in Kwaje (2014) explains the idea of cultural universals, alternatives and specialties in the following way: cultural universals refer to those elements of a culture open to all and shared by every culture bearer. To be competent in a culture implies sharing in its cultural universals. Cultural alternatives are various institutions provided by culture to meet a given cultural demand; and cultural specialties are institutions for 
specialised training and knowledge whose membership may be voluntary or ascribed. The analysis of the role of culture as the very texture of social contract theories and viable human organisations is related to the thematic issues of national security affecting both the persons and the community at large (Gbadegesin, 2010, p.162). This view tends to suggest that the protection and development of a nation-state are culturally contextual.

It is, however, important to note that no nation can achieve total security. According to Goulet (1987), a society may be presumed secure if there is a high probability of the occurrence of its preferred national values. Tukur (1999, p.19) defines values as the highest ethical standards and criteria through which individuals, groups and societies order their goals, determine their choice and judge their conduct as these pertain to fundamental aspects of life, be they in the sphere of personal or public affairs. The capacity to make judgments in interaction with the challenges of the human environment and society helps to formulate and institutionalise essential policies on culture.

There is a wide realisation that the critical area for the solution of a social and national problem is that of culture; since culture has the ultimate values which motivate human and civic action in historical perspective. This position is supported further by the fact that, in securing the various compartments of culture, such as language, customs, norms, art, science, metaphysical belief, there is concomitant security of the human social systems, which in turn creates a sort of individual and community alliance. Hence, the distinctive analysis of culture is historically necessary for any form of security and development. And given the fact that culture and security follow specific autonomous, as well as functionally dependent, dynamic trends regarding social and individual well-being; it is pertinent to analyse their two-tier operational functionalism either as 'culture of security' or as 'security of culture'.

\section{ATTEMPTING A THEORETICAL MATRIX: CULTURE OF SECURITY AND THE SECURITY OF CULTURE}

Culture and security are dynamic social realities which involve continuity and change (Gbadegesin, 2010, p.173). Lifestyle and security cannot be treated outside of cultural values. Ackermann (1981, pp.447 \& 450) posits that cultural values are 'ways of ordering and evaluating objects, experiences and behaviours manifesting themselves in all situations of choice. Cultural values are viewed as a determining factor in the choice and impact of technology; on the other hand, technology is perceived as potentially transforming cultural values'. From the above, Ackermann (1981, p.451) draws the vital conclusion that 'it is important to realize that cultural values and beliefs have a historically acquired force that is to some extent independent of the current social structure. As a result, they will be embodied in the projects of individuals and groups, contribute to the ordering of their priorities, and affect their strategies to achieve whatever goals they have set themselves'.

On the relationship between culture and security, Oladiran \& Adedavoh (2007, p.98), maintains that "if through culture man slowly liberates himself from the chains imposed by nature, then cultural forms acquire ever increasing degrees of perfection to the extent that they permit the unfolding of spirit, that is, the exercise of human freedom". In our effort for national and human security in Africa at large, we can agree with Epskamp \& Boeren (1992) that "we on this African continent can enrich our knowledge and cultural heritage through our cooperative efforts and the pooling of our scientific and technical resources". The goals of culture and security, which we have set before us, require a world order and peace charter derived from the diverse cultures. 
The scholarly approaches to culture attempt to distill a distinction between culture and security, either as a 'culture of security' or as a 'security of culture'. While 'culture of security' refers to the social and contractual orientation that ensures a people's well-being with a community, the 'security of culture' signifies all modalities by which a people's worldview and way of life are ensured. For Castro-Gomez (2002, p.26), the culture of security means all constitutive spheres of moral, religious, political, philosophical and technological values that permit man to 'humanise' himself. For Uroh (1996, p.11), the culture of security in the context of our analysis is a product of a people's experience to enhance their well-being. This means that knowledge about the culture of security depends on the ways people have adopted or acquired it in their attempts to solve socio-historical problems.

In attempting a conceptual framework for this work, a three-tier analysis of culture of security is relevant. The three aspects are ideas, aesthetic forms and values. According to Odhiambo (1999) as cited in Agena (2018, p.7)

the culture of security in a society consists of three distinct elements; ideas give rise to habits and beliefs, aesthetic forms reflect the artistic expression of a culture in its visual arts, the values are formed by the interaction between ideas and aesthetics norms of conduct" with a bid to enhancing human well being

It is therefore, pertinent to evaluate how the culture of security is acquired and socialized by human beings in their society. These different aspects of culture can be challenged by internal and external forces. According to Frantz (1998) the culture of security is an essential element of the history of a people, because it allows us to know how to resolve the nature and extent of the imbalances and conflicts (economic, political and social), which characterize the evolution of a society. A culture of security allows us to know the dynamic synthesis, which have been developed and established by social conscience to resolve these conflicts at each stage of its evolution, in the search for survival and progress. The culture of security means the protective mechanism, which obtains in the land, a community enterprise, a body of laws and morals along with their metaphysical foundations that guide and ensure peace and order within the community. In this context, the culture of security refers to one of numerous distinct systems in which social theory and action are interrelated. It therefore means that the culture of security, as a social system, is dependent on the operation of human personality and positioning. That is, the culture of security is a system abstracted from both protective actions and theories on social existential affairs.

In other words, the culture of security is a system of values, meanings or significance and symbols regarding the structure of social life (Gary, 1997). Accordingly, the culture of security can thus be said to provide the perspective necessary to rethink the meaning of life, and the projection of such purposes from the prevailing circumstances of the present. Given this situation, the culture of security gives us the impetus to leap over obstacles that hamper human and social development and chart new pathways for prospects.

Furthermore, the proper clarification of the beneficial purpose of the culture of human and social security gives a clue as to how to bridge the gap between our means and our ends, and how to appropriate these means and ends for man's technological development and the transformation of the individual and the state in society. Oladiran \& Adedavoh (2007, p.95) points out that: 
there are general principles or ethos governing the security of culture, especially the ones by which culture survives or operates. In this context, the security of culture can be sustained in either a materialised or objectified, as well as an idealised or spiritualised, way. The 'object or material culture' of a people can be those items of culture that can be sustained by empirical verification and justification. This aspect of 'security of culture' is tangible and in fact can be seen, described, and sometimes even touched. Under its tangibility, the characteristics of culture are discernibly protected. Security of the material culture thus comprises material, institutional, philosophical and creative aspects, as contained in our cultural policy and practice

The material security of culture has to do with artifacts in the broadest form (namely: tools, clothing, food, medicine, housing, etc., and institutional monuments such as the political, social, legal and economic structures erected to help achieve material and spiritual objectives). Indeed, the sociological culture of security measures can be adequately and better substantiated by the nature of an object or material culture, that is how the society produces its means of existence and the way the individual members and groups within the society relate to each other and organize themselves within the society, as well as the general code and ideas that bind people together' (Kweme, 1997). Another perspective on the security of culture is that it can be idealised. This idealisation operates at the level of inner dispositions to reality or a metaphysical projection of such a reality. Although this is where the spirit of the people depicts the subjective aspect of culture, nevertheless it depicts the transcendental reality of the African people aptly. Gbadegesin (2010, pp.172-174) states that:

\footnotetext{
For some social and political theorists security of idealised culture consists mainly of diverse ideas as initiators of action, as if ideas have an independent ontological reality moving in the brains of human beings. This means that the Africans guard jealously the process of their inner subjective dispositions. This is necessitated by the fact that the operation of an idea in the mind influences the external world and stratifies it in a definite and particular referential correspondence and behavioural dispositions
}

Against the backdrop of communicating the spiritualised and objectified typologies of culture, the main global method of the security of culture can be seen as a complex linguistic phenomenon, being constitutive of numerous elements of which the picture of the language of the culture is one. Because of the countless constituent aspects of a culture, there is a hybrid of cultural overlap, which makes room for cultural interdependence. Consequently, it is also possible for people trying to preserve them to share many aspects of a culture, without a shared language. This is possible if there is lively participation in the activities, goals, aspirations, and the fate of a broader cultural community (Kweme, 1997, p.44). The term security of culture is, therefore, referred to the totality of Africa's basic protective orientation in life (Dzobo, 1992, p.123). Security of culture in this perspective is an open-ended resource of social meanings upon which members of a community draw to mediate the contingencies of their everyday lives. As such, the phrase denotes the preservation of the material and spiritual resources of a community's material and moral worlds.

\section{THE NEXUS BETWEEN CULTURE AND NATIONAL SECURITY}

Culture as the totality of the way of life of a people has enormous security influence on the nation, because, national security is the concern for the survival, peace and progress of individuals, groups and the society as a cultural whole. Hence, national security is a concept that cannot be easily understood without its application to social and cultural phenomena. Owolabi, (1998) corroborates this statement when he maintains that Security is a concept devoid of operational meaning in the absence of some identification of threats. In all discussions of security from the personal to the international, there is an implicit or explicit determination of risk. 
Owolabi (1998, p.160) states that the threat to cultural perceptions forms the core of the understanding of national security. Particular risk to cultural perceptions of national security can be x-rayed by the weakening of states and communities, their erosion and in some cases even their implosion as well as their incapacity to ensure public order and to fulfill other functions. Amilcar (1998, p.2) observes that, objectively, security is an absence of threat to acquired values such as territorial sovereignty and independence, socio-economic interests and political traditions. Objectively, it is the absence of fear that such values will be infringed. The threat to the existence and survival of a nation comes in two broad spheres; the internal and external threats. An external threat is an attempt originating from outside the country either to destroy land or to force on it a line of action contrary to its interests. External threats usually result from conflict between a nation and another nation or even an international organisation. Internal threats are those unfavourable conditions which may result in conflict that threatens public order. These conditions may be due to social, political, economic, ideological, or ethnic reasons. Internal threats also come about due to influence from outside a country, especially by organisations or groups which promote values antithetical to integration or cohesion in a country. The internalization of such values may result in actions inimical to national security. For any nation to survive it must be appropriately positioned to combat any forms of the above mentioned threats.

On the other hand a nation is considered secured and un-threatened if there is a high occurrence of its preferred values even though no country has absolute security at all times (Kwaje, 2014). However, within the context of impending threats, a nation must put in place adequate measures to limit the possible adverse effects. Coping with perceived threats to a nation's security is actualized through the adaptation of the elements of culture to ensure survival. Such features may be specialised institutions, for example, the military, police, etc., education, cultural institutions, the media, and so on.

\section{SOME SOCIAL AND CULTURAL PROBLEMS CONCERNING SECURITY IN NIGERIA}

One of the most critical dimensions of the security problem faced by the country today is socio-cultural. Culture represents the fountain spring of all policies employed by the government of a nation, be they political, social, economic, or educational (Agena, 2018, p.5). Okwori (2013, p.2) posits that "most of the strategies for development of society hinge on the understanding of the culture of the people". In the case of Nigeria, there has been widespread adoption of Euro-American models for managing the country. Unfortunately, this has not worked very well because the indigenous cultural foundations of the ethnic nations which constitute Nigeria have not been taken into consideration. Our leaders have imbibed the way the colonialists administered Nigeria in the pre-independence era as a national political culture.

The motive for colonisation was the exploitation of resources. The political culture used to hold the nation together was coercion. This explains the reason why some societies have imbibed forceful means of managing their security, which is not working today. The police and the military were set-up to repress protests by the people which threatened the stability of the colonial order. It is this culture that has been acquired in the post-independence era which has brought about the exploitative nature of the political class and a failure of social cohesion due to ethnicity, religious intolerance, the militarisation of politics, economic deprivation and so on (Nicolaides, 2018). 
According to Heywood (2002), the political dimension of the problem is next in importance to the cultural aspect. The evolvement of a new culture dominated by western modes brought about a perverted orientation of the strategy by which a multi-cultural independent Nigeria could be governed. The method used by the colonialists to rule the country was adopted by the nationalists who found themselves at the helm of affairs. Things, however, fell apart due to the exploitation of the resources of the nation, leading to a lack of economic security on the part of the people and a breakdown of law and order.

The economic dimension is the third essential dimension of the security problem. The exploitation of the resources of the nation has brought about a breakdown in social service delivery, and entrenched poverty in the land leading to social and ethnic stratification (Davidson, 1991). It has further worsened the security situation, which often manifests itself in disobedience to law and large-scale conflict claiming many lives and properties. An economic poverty perspective can be perceived in the activities of some multi-national industries which engage in exploitative conduct, often resulting in violent national insecurity (Amilcar, 1998). For example, after the discovery of crude oil, many multi-national companies came in to assist in the development of the oil sector. The exploration of oil led to the degradation of the environment which the host communities relied on for their livelihood.

Also, the necessary infrastructure and amenities such as hospitals, roads, schools, were not provided in many of these communities. How then do people survive when their means of existence have been threatened and there are no contingency plans to remedy the situation? One result has been widespread violence which has claimed many lives, including expatriates and security operatives. Since the various ethnic groups in the area unite against the multinational companies, these companies often employ the strategy of divide-and-rule. It involves the supply of weapons to ethnic groups to fight each other in the quest to position such a group for monetary benefits from these multi-nationals. The wanton destruction of lives and properties in the Niger Delta area has been a significant problem for Nigeria's security forces to control. Another dent to national security is the fact that from the Niger Delta area there has been an influx of light weapons into the wider Nigerian community. What this portends is that such weapons can be used for other criminal activities such as armed robbery, political assassination and so on (Oladiran \& Adadevoh, 2007).

Education as means of cultural transmission has been designed in a manner it was bequeathed Nigerians by the colonialists. School has not functioned particularly well as an agent for transfer of the values cherished by the state (Chukwu-Okoronkwo, 2012). It has failed in the inculcation of viable ethical culture for the tolerance of others. Through a moral education both formally and informally, it becomes possible to see the consequences of involving oneself in any conduct which can destabilise the state. Moral culture is a necessary means of ensuring national security. Questions about national security in Nigeria are more significant due to the emergence and blossoming of a perverted idea of civil protection. It is evident by the proliferation of vigilante groups and ethnic militias that have emerged to fill the gaps and inadequacies in the defence and security functions of the society (Castro-Gomez, 2002).

There is evidence of a negative civilian input in security matters. The unyielding violence in the country has created a fertile substrate for the expansion of such groups. In some areas of the country, the actions of these groups have been institutionalised and legitimised. The socalled, 'area boys' and 'Almajiri' are recruited for the amplification of ethno-religious conflicts around the country. Small bands of political thugs known as 'Ecomog' are employed as personal security for political office holders, and for political violence. 
However, the dangerous aspect is that they have received some legitimacy and now form part of the regular entourage of political leaders. There has been a more dangerous trend in the proliferation of ethnic militia and other dubious non-conventional community security and defence outfits, which have been put in place for the service of more extentsive political, regional and economic interests (Egwu, 2015). The forms of violence produced by these ethnic militia groups surpass even the other unstable times. These militia groups retain the capability for violence and mayhem that are unrivalled in intensity. They are often capable of contending with the institutionalized violence of the military (Peters, 2010).

\section{THE WAY FORWARD}

A critical examination of the various cultural problems which threaten Nigeria's national security reveals that they are related in the cultural dimension. A lack of understanding of the far-reaching consequences of some of these social actions remains one crucial reason why it has been possible to subvert the Nigerian state. As a post-colonial African state and a developing nation for that matter, it is essential to develop a cultural transmission method through formal and informal education that will help create a greater awakening to the fundamental problem of Nigeria, which is an ethical one. There is the need to create a vision of a Nigerian dream in which the different groups have roles to play, despite our differences. There is the need to unite the various groups through the stressing of those areas, within similar cultures as a way of putting an end to the issue of stratification in the society. Very importantly, there is a need for an ethically based leadership. It is, therefore, necessary to enlighten Nigerians about the dangers of exposing ourselves to different cultural ideas, which can destabilise the country. It is necessary because culture provides all sorts of nuances in communication and the amalgamation of the ethics of protective differences and communal solidarity necessary for national security.

There is a need to involve educational institutions in the area of security. The formal educational sector needs to be re-invented by incorporating a curriculum on critical ethical education directed at breaking ethnically bound values, religious barriers and so forth. It is necessary to promote and teach social ethics to raise the moral consciousness of citizens. The use of electronic media will also prove very useful in this effort because a broader population can be covered in this way. It also pertinent to involve the various Councils for Arts and Culture in the states and at the Federal level. Such cultural administration establishments should be adequately staffed with people trained in applied anthropological research methods. These cultural centres can assist in researching on the kinds of collective conduct in the society which disturb peace and stability.

\section{CONCLUSION}

This work has emphasised the significance of a national cultural policy as an instrument of security and social engineering. It is crucial for national survival, insofar as national security is, in a significant sense, a product of culture. The critical clarification and interconnections of the material, institutional, and philosophical aspects of culture paved the way for a more systematic analysis of the dynamic elements of our culture(s) vis-à-vis national security. This cultural analysis situated the internal and external dimensions to national security. The article has revealed an avalanche of ethno-religious security related challenges in Nigeria. It therefore, recommends cultural education for value reorientation towards a safer society. 


\section{REFERENCES}

Abah, O. S. ( 2007). "Vignettes of communities in action: an exploration participatory methodologies in promoting community development in Nigeria", Community Development Journal, Vol. 42 No. 4,

Ackermann,W.(1981). 'Cultural Values and Social Choice of Technology', International Social Science Journal, vol. XXXIII, no. 3, 447-465.

Agena, M. M.( 2018). "Cultural Globalization and the Quest for Social Security in Nigeria" in Gowon, A. D. (Ed) Banchi: Nasarawa Journal of Theatre and Media Arts Vol, 5. No. 2, Savehage Publishers.

Amilcar, C. (1998). 'National Liberation and Culture (Return to the Source)', in Emmanuel Chukwudi Eze, ed., African Philosophy: An Anthology, Massachusetts: Blackwell, pp. 260-265.

Castro-Gomez, S. (2002). 'The Cultural and Critical Context of Postcolonialism', Philosophia Africana, vol. 5, no. 2, pp. 25-34.

Chukwu-Okoronkwo, S. (2012). "Nigerian Popular Theatre Alliance (NPTA) Further Dimension in Trends of Alternative Theatre Practice in Ahmadu Bello University, Zaria Nigeria”. International Journal of Academic Research in Progressive Education and Development, Vol. 1, No. 1,

Davidson, B. (1991). 'What Development Model?' African Forum - A Journal of Leadership and Development, vol. 1, pp. 13-16.

Dzobo, N. K. (1992). 'The Image of Man in Africa', in Kwasi Wiredu and Kwame Gyekye, eds., Person and Community: Ghanaian Philosophical Studies 1, Washington DC: The Council for Research in Africa, pp. 123-132.

Egwu, S. (2015). "The Political Economy of Rural Bandity in Contemporary Nigeria” in Kuna, M. I \& Ibrahim, J. Ed Rural Bandity and Conflicts in Northern Nigeria. Abuja: CDD,

Epskamp, K \& Boeren, A. (Eds) (1992). The Empowerment of Culture: Development Communication and Popular Media. The Hague: Centre for the Study of Education in Development Countries.

Frantz, F. (1998). 'Racism and Culture', in African Philosophy: Anthology, Massachusetts: Blackwell, pp. 305-311. 1998

Gary, F. (1997). Cultural Anthropology: An Applied Perspective: Wadswort Publishing.

Gbadegesin, S. (2010). 'Contemporary African Realities: The Cultural View', in Africa Philosophy, Traditional Yoruba Philosophy and Contemporary African Realities,

Goulet, D. (1987). 'Culture and Traditional Values in Development', in Philip J. Hughes (ed). The Ethics of Development: The Pacific in the 21st Century, Port Moresby: University of Papua, New Guinea Press, pp. 165-178. 
Gyong, J.E. (2017 ). "Security Challenges in Nigeria and the Impact on the Education Sector.” A Lead Conference Paper Presented at the School of Arts and Social Sciences , FCE Zaria

Heywood, A. (2002). Politics, Second Edition. Palgrave Macmillan

Idebe, A. (2018). "Theatre for Development in Terrorised Spaces: The Birin Gwari TFD Expirience". SONTA Publication

Kwaja, C. (2014 ). "Blood, Cattle, and Cash: Cattle Rustling and Nigeria's Bourgeoning Underground Economy" in West Africa Insight, 4, 3,

Kwame, G. (1997). Tradition and Modernity. Philosophical Reflections on the African Experience.

Mohammed, J. A. \& Ihidero, V.O. (2018). "Theatre for Development as a Tool for Countering Rural Banditry: The Maganda TFD Experience”. SONTA Publication

Nicolaides A. (2018). "Globalization and Americanization- The Hijacking of Indigenous African culture." Global Advanced Research Journal of History, Political Science and International Relations, 1(6). 2012. Web . 2 April,

Okwori, J. Z. (2013). "Cultural Analysis as an Essentialising Tool for Development Planning” A Faculty Seminar presented at the Faculty of Arts, ABU, Zaria. January, 13.

Oladiran, O. \& Adadevoh, I.O. (2007). Cultural Dimension of National Security Problem. https://www.culture-and-national-security. Accessed 20/05/2019

Owolabi, A. O. (1998). 'Global Change: Redefining African National Security in the 90s and the Twenty-First Century', in Olusegun Oladipo, ed., Remaking Africa: Challenges of the Twenty-first Century, Hope Publications, pp. 159-167.

Peters, G. (2010). Crime and Insurgency in the Tribal Areas of Afghanistan and Pakistan. Combating Terrorism Centre at Westpoint

Tukur, M, (1999). Leadership and Governance in Nigeria. The Relevance of Values. Hodder and Stoughton.

Uchendu, V. C. (1988). 'Towards a Strategic Concept of Culture: Implications for Continental Unity in Africa', in The Cultural Foundations, Civitelis International.

Uroh, C.O.(1996). 'Africa in The Philosophy of Culture: Demystifying an Ideology of Cultural Imperialism', Journal of Philosophy and Development, vol. 2, 